\title{
Development of a measure for perceived employment relationship quality (PERQ)
}

\author{
by Willem Potgieter ${ }^{*}$, Chantal Olckers \\ and Lukas Ehlers
}

\begin{abstract}
Studies have shown that employees react negatively towards negative supervisory behaviour. Therefore, a questionnaire that could measure the quality of various aspects of the employment relationship could be a useful tool for managing and promoting healthy employment relationships. In the light of this, the aim of this study was to develop a questionnaire that measured the perceived quality of the employment relationship from the employee's perspective. A quantitative cross-sectional survey was conducted on a non-probability convenience sample of 248 employees from various organisations and sectors in South Africa. Although a 39-item questionnaire was developed across four theoretical dimensions, namely trust, fairness, good faith and justice, the analysis revealed that only two dimensions, labelled social factors and compliance factors and measured by 20 items, were sufficient to measure the desired construct. This questionnaire, which measures the perceived employment relationship quality, could be used as a diagnostic tool by management and HR professionals to determine the state of supervisory relationships in an organisation, and to address any problems brought to the fore, thereby avoiding turnover costs related to negative workplace relationships.
\end{abstract}

Key words: employment, relationship, quality, measure, supervision, perceptions

\section{Introduction}

Employment relationship outcomes can be influenced by a host of relationship behaviours, which are commonly motivated by the explicit or implicit relationship expectations of employers and/or employees (Bendix 2010a; Deci, Connell \& Ryan 1989; Ehlers 2013; Roehling 1997; Rousseau 1995; Shore \& Barksdale 1998).

These expectations can be rooted in objective legal and contractual provisions that are clearly defined or implied in a formal employment contract, or in a multitude of highly subjective and inconsistent perceptions that are encapsulated in psychological contracts (De la Rosa Navarro \& Cabrera 2009; Rousseau 1995). It is thus virtually impossible to define and state measurement criteria for all rights, obligations and expectations in an employment relationship in a single comprehensive contractual document (Ehlers 2013).

\footnotetext{
Mr Willem Potgieter is a Master's student at the University of Pretoria.

Prof Chantal Olckers, is an Associate Professor in the Department of Human Resource Management in the Faculty of Economic and Management Sciences at the University of Pretoria.

Dr Lukas Ehlers is a Senior Lecturer at the Tshwane University of Technology.
}

Correspondence to: Prof C Olckers, Department of Human Resource Management, Faculty of Economic and Management Sciences, University of Pretoria, P/Bag X20, Hatfield, 0028. E-mail: chantal.olckers@up.ac.za 
Objective measurement and analysis of employment relationship behaviour and outcomes in South African organisations are further complicated by the influence of a multitude of racial, gender, ethnic, cultural, educational, social, economic and political imbalances and differences in the South African labour force (Bendix 2010a; Coetzee \& Bezuidenhout 2011). These imbalances have necessitated the introduction of a variety of social labour laws aimed at protecting and advancing fair and equitable treatment of employees. All expectations of reciprocal rights and duties related to workplace fairness and equity are, however, not always explicitly aligned with the provisions of South African labour laws or related codes of good practice, which in turn creates opportunities for employers or employees to align their relationship expectations and behaviour with their own subjective situation-bound interpretations and needs in regard to these rights and duties, which are related to workplace fairness and equity.

South African employment relationship participants, practitioners and researchers are confronted with the task of analysing a host of dynamic singular and hybrid variables and related outcomes that occur in countless configurations in order to identify best practices for securing mutually desirable employment relationship outcomes. The identification, measurement and management of employment relationship variables that cause or relate to desired relationship outcomes consequently pose a major challenge for employment relationship researchers and practitioners (Sparrow \& Cooper 2003).

Ehlers (2013) has identified various aspects of the social conditions desirable in supervisory relationships and has integrated his findings to develop a typology which illustrates how the social dimensions in a supervisory relationship interact with one another. These dimensions may be important in determining how day-to-day social transactions take place and whether the transactions will be harmonious or hostile in nature. This study will refer to this phenomenon as the quality of the employment relationship. If we were able to identify the strengths and weaknesses of a manager according to the perceptions of his or her subordinates, an organisation could gain immense value by using such information to take either remedial or reinforcing action.

Currently there is no validated instrument that measures the quality of the employment relationship (also referred to in this study as a supervisory relationship) in this format. If such an instrument could be designed, managers and supervisors would stand to gain important knowledge of how they were perceived by their subordinates; they could then take the necessary steps to mend and manage this vital relationship.

\section{Aim of the study}

Studies have shown that employees react negatively to supervisory behaviour that is perceived as negative, by engaging in behaviour that is potentially harmful to the organisation and its members (Guest 2004; Hallier \& James 1997; Rousseau 1998; Shore, Sy \& Strauss, 2006; Tekleab \& Taylor 2003; Thau, Bennett, Mitchell \& Marrs, 2009). This type of behaviour includes poor work performance, deviant work behaviour or resignation. Positive supervisory treatment, however, promotes desirable outcomes such as job satisfaction, citizenship and organisational trust.

The aim of this study was to develop a valid and reliable measure of the perceived quality of supervisory relationships (relationships between employees and direct superiors) from the perspective of employees. If supervisors and practitioners were able to identify the strengths and weaknesses of a manager according to the perceptions of his or her subordinates, an organisation could gain immense value by using such information to take either remedial or reinforcing action. 
The purpose of this questionnaire is to address specific desirable social conditions of a good-quality employment relationship. Although the questionnaire is intended to measure only one construct, namely the Perceived Quality of Employment Relationship (PERQ), it will comprise several relevant dimensions and mediators of this construct. The questionnaire will therefore not only provide a high or low score on the construct measured, but will point out areas of the supervisory relationship that need to be addressed or rewarded.

Such an instrument should be able to measure perceptions related to traditional mediators of the quality of supervisory relationships, as well as perceptions related to modern mediators of employment relationship quality, such as meticulous compliance with labour laws and demonstration of dominant societal expectations as regards fairness and equity in supervisory behaviour. Although the Minnesota Satisfaction Index and other similar measures include a number of items that are aimed at measuring subordinate satisfaction and some aspects of supervisory behaviour, they do not measure satisfaction with perceived organisational justice, leader-member exchange, perceived organisational support and organisational trust levels, which are widely regarded as mediators of organisational relationship quality (Sparrow \& Cooper 2003). These mediators are all strongly related to the conditions in and the quality of supervisory relationships. The validated typology of desirable social conditions in supervisory relationships developed by Ehlers (2013), which encapsulates the aforementioned mediators of organisational relationship quality, formed the theoretical base for the development of the questionnaire in this study.

\section{Literature review}

\subsection{Employment relationship quality}

Employment relationship quality (ERQ) refers to the extent to which parties to the relationship experience interactions, exchanges and various mediators associated with a work relationship as positive or negative. Good ERQ will be evident when both economic and social exchanges (De la Rosa Navarro \& Cabrera 2009) between employers (supervisors) and employees are experienced as positive and harmonious from the perspective of both employers and employees.

\subsection{Primary determinants of employment relationship quality}

The supervisory relationship is widely regarded as a vital relationship in all types of organisations (Nelson \& Friedlander 2001; Wallace, Hunt \& Richards 1999; Whitener, Brodt, Korsgaard \& Werner 2014). The relationship between positive supervisory behaviour and higher levels of job satisfaction has been confirmed by numerous authors, and the adverse impact of negative supervision on job satisfaction levels has also been highlighted (Coyle-Shapiro \& Shore 2007; Gould-Williams 2003; Kickul, Gundry \& Posig 2005; Robbins \& Judge 2011; Searle \& Skinner 2011). Unfortunately, because supervisory relationships are situation-specific, there are no universally applicable generic guidelines for positive treatment of subordinates. Negative supervisory behaviour can cause various undesirable organisational outcomes, such as deviant employee behaviour, destructive workplace conflict, employee grievances, labour disputes and the resignation of employees (Robbins \& Judge 2011:64; Tepper et al 2009). 
In describing a theory of perceived organisational support, Shanock and Eisenberger (2006) explained that employees assigned anthropomorphic characteristics to their employer's organisational structures, systems and behaviour, and tended to view the organisation as a single interactive living entity that interacted with employees through their direct supervisor. The immediate supervisor is therefore viewed as the primary representative of a whole organisation (Bendix 2010b). Employees consequently perceive the positive or negative behaviour of immediate supervisors as the behaviour of the organisation in which they are employed (Bendix 2010b). Hence it is argued that the relationship behaviour of an immediate superior will be the primary, although not the only, determinant of the perceptions of employment relationship quality that a subordinate employee will form. Once the importance of the employment relationship has been established, it must be managed effectively. As with any relationship, be it one of friendship, marriage, or work, there are certain factors that will determine the characteristics of the relationship. The dimensions or factors that determine the quality of the relationship are referred to as mediators of the relationship.

Sparrow and Cooper (2003) established that the perceived quality of social exchanges in organisational or employment relationships was modified by four primary mediators. These are: perceived organisational justice (POJ); perceived organisational support (POS); leader-member exchange (LMX); and organisational trust levels (OTL). Table 1 illustrates how the four mediators are interpreted and experienced by the employee.

Table 1

Mediators of quality of organisational relationships

\begin{tabular}{|l|l|}
\hline \multicolumn{1}{|c|}{ Mediator } & \multicolumn{1}{c|}{ Description } \\
\hline $\begin{array}{l}\text { Perceived } \\
\text { organisational } \\
\text { justice (POJ) }\end{array}$ & $\begin{array}{l}\text { Employee perceptions on the presence of three forms of organisational } \\
\text { justice, namely: }\end{array}$ \\
\hline $\begin{array}{l}\text { Distributive justice (equity in distribution of work and resources). } \\
\text { Procedural justice (fair, ethical and consistent application of policies and } \\
\text { procedures). } \\
\text { Interactional justice (fair treatment in interpersonal relationships). }\end{array}$ \\
$\begin{array}{l}\text { Perceived } \\
\text { organisational }\end{array}$ & $\begin{array}{l}\text { General employee perceptions on the extent to which the organisation cares } \\
\text { about employee well-being and the extent to which employee contribution is } \\
\text { valued. POS theory holds that a subordinate will perceive the actions of an } \\
\text { immediate superior as the actions of the employer as a whole. }\end{array}$ \\
\hline $\begin{array}{l}\text { Leader-member } \\
\text { exchange (LMX) }\end{array}$ & $\begin{array}{l}\text { Perceptions on the direction and support received from a supervisor, and the } \\
\text { general quality of the unique relationship between a supervisor and an } \\
\text { individual subordinate. The quality of this relationship depends on interrelated } \\
\text { experiences of respect, trust and mutual obligation. }\end{array}$ \\
\hline $\begin{array}{l}\text { Organisational trust } \\
\text { levels (OTL) }\end{array}$ & $\begin{array}{l}\text { Perceptions of the levels of trust in the relationship between employee and } \\
\text { organisation, and how organisational change and relationship behaviour affect } \\
\text { the trust relationship. }\end{array}$ \\
\hline
\end{tabular}

Adapted from Sparrow \& Cooper (2003).

To summarise table 1 , the quality of the employment relationship that the employees experience is determined by their perception of the organisation's fairness in terms of distributing work and equal treatment with regard to policies and relationships. Employees will furthermore expect support from the organisation, but more importantly they will expect this from their supervisors (leaders). A lot of emphasis is placed on mutual responsibility and the trust that is earned when this responsibility is fulfilled by both parties. 
Table 1 suggests that the perceptions of employees, and not necessarily those of their superiors, are more important. Employees feel that they need to be able to trust their superiors to be fair and supportive in their day-to-day exchanges. If employees do not perceive or experience these conditions from their point of view, it would be futile for management to claim to be cooperating.

Ehlers (2013) conducted an in-depth inquiry into the determinants of desirable supervisory relationships and subsequently developed a reliable typology for desirable supervisory relationships. This typology was informed by literature review findings on an employment relations typology developed by De la Rosa Navarro and Cabrera (2009) and on mediators of organisational relationship quality (Sparrow \& Cooper 2003) and the relationship between employment relationship behaviour and supervision.

The typology of Ehlers (2013) is displayed in Figure 1.

Figure 1

Relationship between trust, good faith, fairness and justice

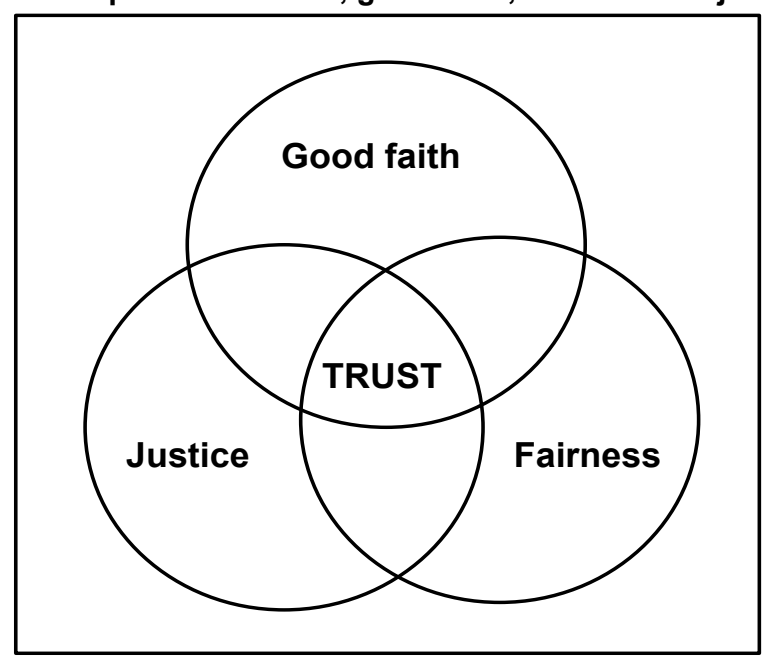

The typology specifies trust, good faith, fairness and justice as interrelated employment relationship conditions that are significantly related to good quality supervisory relationships, and are thus desirable in such relationships. According to Ehlers (2013), these mediators interrelate to influence the quality of the relationship experienced between superior and subordinate. The four mediators also formed the four dimensions of the construct that would determine PERQ, the instrument this study aimed to develop. Each one of these mediators will be described in greater detail.

\subsubsection{Trust}

Literature related to employment relations and organisational behaviour has proposed numerous definitions of trust. Burke, Sims, Lazzara and Salas (2007) reviewed various definitions of trust and concluded that trust is a process that affects behaviour directly. This statement is supported by Khodyakov (2007), who used communication as an example to demonstrate the intervening effect of trust. The level of trust of employees towards their superior will determine the level of communication in the relationship. Trust is a relatively stable individual trait but can emerge or change dynamically in response to changes in relationship conditions. 
Trust implies that a person is willing to rely on the actions or decisions of another to reach an outcome that is beneficial and not detrimental (Bews \& Uys 2002; Clark \& Payne 1997; Sparrow \& Cooper 2003).

\section{Moderating effects of trust on the employment relationship}

Trust and the levels thereof will affect the various role-players in the labour relationship in different ways. Ehlers (2013) postulates that employees who trust their organisations will work harder at fulfilling their roles in the organisation than those who do not trust the organisation. Kickul, Gundry and Posig (2005) found that people who distrust their organisation will be more sensitive towards issues such as fairness and equity. Furthermore, both Gould-Williams (2003) and Coyle-Shapiro and Shore (2007) found that supervisory practices and leadership are positive predictors of trust. In other words, employees are more likely to trust their superiors if they display strong leadership and engage in good HRM practices. The behaviour of management will therefore have a significant influence on employees' levels of trust (Searle \& Skinner 2011) and, by implication, on other work-related variables such as performance and job satisfaction (Coyle-Shapiro \& Shore 2007). Robbins and Judge (2011) have similarly concluded that a strong relationship exists between the behaviour of subordinates and the extent to which they perceive their leaders to be trustworthy. Robbins and Judge also found that a superior's integrity, expertise and willingness to protect his or her subordinates are important determinants of whether an employee will trust the superior or not.

It can therefore be confidently concluded that the way in which supervisors (managers) conduct themselves in an organisation will have a significant effect on the levels of trust of their employees. Furthermore, the extent to which employees trust their superiors will have a significant effect on their loyalty and commitment to their organisations. Trust is therefore considered to be a very important factor to manage in the employment relationship.

\subsubsection{Fairness}

People may have different perceptions with regard to fairness; there are, however, certain standards of fairness that are universally accepted (Ehlers 2013). The importance of fairness is a major theme in South African legislation. When "fairness" is debated in the justice system, the "reasonable man" test is often applied (Colquitt, Conlon, Wesson, Porter \& $\mathrm{Ng}$ 2001). In this case the question that is asked is, "Would any reasonable man have acted in the same way as the perpetrator in that specific situation?" The concept of reciprocity also comes to mind when determining whether certain actions or situations can be deemed fair or not. Kolm (2006) confirms this by stating that reciprocity is related to fairness and equal treatment. In this case the contracting party may be asked if they would deem it fair if the same action were executed against them.

Fairness is achieved when people are not prejudged and treated inconsistently in comparison with their colleagues (Bendix 2010a). Cremer and Tyler (2007) established that procedural fairness in making and implementing rules is an important variable that positively affects cooperation in employment relationships.

Salamon (1987) concluded that in order for there to be fairness in an employment relationship: (1) there should be reciprocity; (2) one party should not benefit at the expense of the other; (3) there should be a give-and-take exchange in the relationship; (4) both parties should receive equal treatment and equal consideration in that the same criteria and considerations should apply and (5) as a whole, the treatment people receive should be consistent. 


\section{Moderating effects of perceived fairness}

Gerlach, Levine, Stephan and Struck (2007) found that employees who feel that they have been unfairly treated may deliberately restrict output or even resort to sabotage. Southey (2010) confirms this in his statement by saying that unfair treatment of employees in the workplace inhibits performance and commitment of employees. Southey further found that these perceptions prompted a number of employees in the sample in his study to engage in undesirable organisational behaviour, which ultimately resulted in their dismissal. The opposite was also found to be true by Gerlach et al (2007). Employees who feel they are being treated fairly are more likely to do more than the bare minimum that their jobs require of them.

Considering the above statements, it can be confidently concluded that employees need to experience fair treatment at work. Failure to create such an environment may have detrimental effects on the productivity, commitment and morale of employees. Although fairness may be in the eye of the beholder, there are ways of establishing the fairness of a situation, be it legally or through conciliation. There is no doubt that the perception of fairness by both parties depends on a mutual commitment to good faith by everyone involved.

\subsubsection{Justice}

Cropanzana, Bowen, Gilliland and Bowen (2007) argue that organisational justice could potentially create powerful benefits such as increased trust and commitment, improved performance, competitive advantage, improved customer satisfaction and less conflict in employment relationships. Furthermore, Cropanzana et al (2007) believe that justice does not necessarily mean that the employees have reached their desired outcome, but the perception of justice will act as a buffer against disappointment. Employees might be slightly less aggrieved when matters do not turn out as they desire if they perceive management as having acted justly.

Once the importance of perceived justice in organisations has been established, it is important to look at some definitions of justice. There are, however, many different definitions and perceptions of justice in the literature. Organisational justice is often related to fairness and equity in the workplace (Coetzee \& Bezuidenhout 2011; Greenberg 2001; Sparrow \& Cooper 2003). Lind and Van den Bos (2002) argue, however, that the words "justice" and "fairness" have very different meanings in the English language. They believe that "justice" is more normative, in the sense that it can often be determined by referring to legislative sources. They regard "fairness" as pertaining more to the popular notion of treating people even-handedly in relationships. In the light of the aforementioned, a more precise differentiation between "fairness" and "justice" is required.

In a review of the past 25 years' organisational justice research, Colquitt et al (2001) describe organisational justice as a field that focuses on the antecedents and consequences of fairness in the distribution of outcomes, and the fairness of the procedures used to determine outcome distribution. Ehlers (2013) also conducted a comprehensive literature review and compiled a list of three types of organisational justice based on the findings of Cropanzano et al (2007), Coetzee and Bezuidenhout (2011) and Sparrow and Cooper (2003): (1) Distributive justice: the fair and equitable distribution of work and resources. This type of justice is believed to be strongly related to perceptions of equity (Adams 1965). (2) Procedural justice: the ethical, consistent and fair application of workplace policies and procedures. Thibaut and Walker (1975) concluded that employees who had procedures at their disposal that enabled them to 
voice their opinions would experience higher levels of procedural justice and (3) Interactional justice: the demonstration of trustworthiness, respect and good faith in relationships. Nowakowski and Conlon (2005) argue that interactional justice can be divided into two separate forms of justice: interpersonal justice, which relates to the sensitivity, politeness and respect for people that superiors display during interactions, and informational justice, which relates to the explanation, justification and type of information that supervisors provide to justify their decisions.

Justice in organisations seems to be related to both fairness and trust in an organisation. A pattern of interconnectivity between the mediators of the employment relationship is evident. Although trust, fairness and justice are separate phenomena with their own bodies of knowledge, the one seems to affect the other without exception. If trust is to be experienced by an employee or employer, there must be justice and fairness in some form in the behaviour of both. Justice, however, can be seen as the fair allocation of resources, the allocation of which can be justified by a fair procedure and sincere interaction between parties.

\subsubsection{Good faith}

The concept of good faith is currently in an evolving phase and has no universal definition in terms of the employment relationship (Furlow 2009; Ehlers 2013). The duty to act in good faith, however, is implied in South African labour legislation in various codes of good practice (see Labour Relations Act 66 of 1995, 2002). The guidelines are clear and refer to concepts such as free will (voluntariness), the duty to disclose certain information, the duty to keep certain information secret and the duty to abstain from duress or undue influence. Legislation seems, however, to refrain from using the term "good faith" and instead makes provision for the duty to act in good faith by recommending the above codes of good practice. Good faith and the determination thereof could differ from one situation to another. Therefore, a definition of good faith should be agreed upon prior to the conclusion of the contract.

A lack of good faith by a party to an employment relationship can be considered an act of bad faith. This may become evident when negotiations take place and either one or all parties enter negotiations with no intention of reaching an agreement, when performance is refused by one or more role-players in the relationship and when people bargain with no intention of compromising (Shimanskaya 2010). Grogan (2009) regards dishonesty or insincerity by either employer or employee as an act of bad faith. Examples of these types of behaviour are: unfair discrimination, harassment, victimisation, abusive behaviour, theft, fraud, corruption and intentional poor performance. Acts of bad faith may have serious repercussions and could be detrimental to the employment relationship.

Fundamentally, to act in good faith means that there is an absence of bad faith in the actions of a contracting party. In other words, the contracting party is acting honestly and is applying acceptable commercial standards in its transactions. This also implies that the contracting party is entering into dealings with an open mind and a preparedness to reach agreement. Good faith does not, however, imply that the parties have to act charitably towards each other (Ehlers 2013). It only implies that the parties involved must demonstrate good faith by cooperating in such a way that both parties to the relationship are able to receive the agreed benefits of the relationship. Good faith requires that parties to the employment relationship adopt less combative approaches when entering into negotiations and agreements. This will in turn promote and protect the interests of all the parties involved. Good faith therefore implies that contracting 
parties should be honest, sincere, fair and cooperative during dispute settlements, performance management, collective bargaining, contracting, negotiating and all other forms of interaction in the employment relationship (Ehlers 2013).

\section{Determinants of good faith}

According to Ehlers (2013), parties in the employment relationship can be legally or morally obliged to bargain in good faith. The general principles related to bargaining in good faith should be applied equally, regardless of whether one is dealing with collective or individual employment relations. The following ten duties were identified by Ehlers (2013). These duties need to be performed in order to meet the obligation of good faith in South African employment relationships (Bendix 2010a, Grogan 2009, Venter \& Levy 2011): (1) Displaying sincere intentions to achieve resolutions; (2) making proposals and concessions which demonstrate good faith; (3) abstaining from delaying tactics; (4) not making unilateral changes to the bargaining process; (5) not setting unreasonable preconditions for bargaining; (6) not bypassing acknowledged bargaining agents; (7) providing sound motivations or arguments for positions; (8) not making sudden changes to bargaining conditions; (9) not withholding relevant information without good reason, and (10) abstaining from insulting behaviour.

Nowakowski and Conlon (2005) further concluded that good faith in interactions will become evident when managers or subordinates show politeness, sensitivity and respect for people in their interactions. Good faith also becomes evident when contractors share information relevant to the relationship in a reasonable, comprehensive, truthful and timely manner. Other researchers (Botha \& Moalusi 2010; Mclnnis, Meyer \& Feldman 2009; Guest 2004) have established that perceptions of good faith are related to levels of trust in organisations and perceptions of the state of the psychological contract between parties.

Table 2 summarises the findings of the dimensions identified by Ehlers (2013) as referred to by various authors and provides a good indication of each dimension and its characteristics. The characteristics are those that were found to be important and prevalent in each dimension. This table helped to form the base from which items were developed in the questionnaire used in this study.

Table 2

Relationships between views

\begin{tabular}{|l|l|l|l|l|}
\hline Dimensions & \multicolumn{1}{|c|}{$\begin{array}{c}\text { Related } \\
\text { dimensions } \\
\text { (De la Rosa } \\
\text { Navarro \& Cabrera } \\
\text { 2009) }\end{array}$} & $\begin{array}{c}\text { Related mediators } \\
\text { (Sparrow \& Cooper } \\
\text { 2003) }\end{array}$ & $\begin{array}{c}\text { Related types of } \\
\text { justice } \\
\text { (Nowakowski \& } \\
\text { Conlon 2005) }\end{array}$ & $\begin{array}{c}\text { Typology of } \\
\text { desirable ER } \\
\text { conditions } \\
\text { (Ehlers 2013) }\end{array}$ \\
\hline Trust & $\begin{array}{l}\text { Social exchanges } \\
\text { (Trust) }\end{array}$ & $\begin{array}{l}\text { Organisational trust } \\
\text { levels (OTL) }\end{array}$ & $\begin{array}{l}\text { Procedural } \\
\text { Informational } \\
\text { Distributive } \\
\text { Interactional } \\
\text { Interpersonal }\end{array}$ & $\begin{array}{l}\text { Trust } \\
\text { Requires justice, } \\
\text { fairness and good } \\
\text { faith - among } \\
\text { others }\end{array}$ \\
\hline Good faith & $\begin{array}{l}\text { Social exchange } \\
\text { (Values, belief) }\end{array}$ & $\begin{array}{l}\text { Leader/member } \\
\text { exchange (LMX) }\end{array}$ & $\begin{array}{l}\text { Interpersonal } \\
\text { Informational }\end{array}$ & $\begin{array}{l}\text { Good faith } \\
\text { behaviour: } \\
\text { Sincere } \\
\text { - } \\
\text { Respectful } \\
\text { Considerate }\end{array}$ \\
\hline
\end{tabular}




\begin{tabular}{|l|l|l|l|l|}
\hline Fairness & $\begin{array}{l}\text { Social exchange } \\
\text { (Norms, equity } \\
\text { values) }\end{array}$ & $\begin{array}{l}\text { Perceived } \\
\text { organisational } \\
\text { support (POS) }\end{array}$ & $\begin{array}{l}\text { Interactional } \\
\text { Distributive }\end{array}$ & $\begin{array}{l}\text { Fairness } \\
\text { behaviour: } \\
\text { Objective } \\
\text { Equitable } \\
\text { Eonsistent } \\
\text { Cons } \\
\text { Reciprocal }\end{array}$ \\
\hline Justice & $\begin{array}{l}\text { Economic exchange } \\
\text { (Contracts, rules) }\end{array}$ & $\begin{array}{l}\text { Perceived } \\
\text { organisational } \\
\text { justice (POJ) }\end{array}$ & Procedural & $\begin{array}{l}\text { Justice } \\
\text { behaviour: } \\
\text { Informational } \\
\text { Legal } \\
\text { Contractual } \\
\text { Directional } \\
\text { Procedural }\end{array}$ \\
\hline
\end{tabular}

Source: Ehlers (2013)

The aim of this literature study was to gain an understanding of the dimensions that will affect the quality of the employment relationship, for the purpose of developing an instrument that could measure the latter construct.

\section{Research design}

\subsection{Research approach}

A quantitative cross-sectional survey-based research design was employed to achieve the research objectives. According to Graziano and Raulin (2004), cross-sectional studies are less costly and time-consuming than longitudinal studies, because measurement takes place at one specific point in time, as opposed to longitudinal studies, where measurement takes place over a longer period of time.

\subsection{Research method}

The Perceived Employment Relationship Quality (PERQ) questionnaire was developed by following a six-phase approach derived from the work of various experts on questionnaire development (DeVellis 2012; Hinkin 1998; Rattray \& Jones 2007).

\subsection{Phases in the development of a questionnaire that measures $P E R Q$}

Phase 1: Identifying what the questionnaire will measure

The first step was to clearly define which construct the questionnaire aimed to measure (DeVellis 2012). The typology developed by Ehlers (2013) formed the theoretical base of the construct the questionnaire aimed to measure. The related dimensions of PERQ, as specified by the typology, namely, trust, fairness, good faith and compliance, were clearly defined in the literature review.

Phase 2: Determining the type of scale to be used

Since the questionnaire aimed to measure perceptions employees had of their superiors, a Likert-type scale was the appropriate scale to use (DeVellis 2012). A seven-point scale was chosen, since using an odd number of responses allows for uncertainty. This could also be a limitation, however, because if an even number of responses had been requested, the respondents would have been compelled to make at least a weak commitment in the direction of one or other extreme. Another disadvantage of using a 7-point Likert-type scale is that it takes longer to complete and 
is influenced by response-style bias. According to DeVellis (2012), when designing a new scale it is common practice to include six possible responses and to add a midpoint, as was done in this study.

\section{Phase 3: Generating a pool of items}

A deductive approach (Hinkin 1998) was followed to generate items for the four dimensions of PERQ, namely, trust, fairness, good faith and justice. To represent these four theory-driven dimensions of PERQ, 39 positively directed items (Barnette 2000; Woods 2006) were generated. Each item was substantiated by relevant literature, as illustrated in Addendum 1. This was done to ensure the content validity of the items. To make sure that no characteristic had been omitted, the researchers generated between seven and fifteen items per dimension (Hair, Black, Babin, Anderson \& Tatham 2006). The numbers of items representing the dimensions were as follows: trust (11 items), fairness (9 items), good faith (12 items) and compliance (7 items).

\section{Phase 4: Item review}

In order to identify problematic items in the questionnaire, the pool of items was reviewed by a panel of four experts (Grant \& Davis 1997) who were chosen for their expertise in questionnaire and item development, as well as their knowledge of employment relationships. The panel judged the pool of items on item content, item style and the comprehensiveness of the instrument.

Based on the comments of the panel of experts, none of the items was deleted, although some of the items that had been pointed out as being unclear were subsequently rephrased.

\section{Phase 5: Data collection and procedure followed}

The target population for this study included any employee with at least a matric qualification. More specifically, to participate in the study a person had to be employed and had to report to a supervisor. Managers did not qualify to take part in the study owing to their alignment with their employers (Bendix 2010b).

A non-probability convenient sample of 248 respondents consisting of employees reporting to supervisors was collected. A sample of 248 was deemed sufficient for conducting an exploratory factor analysis (Hair et al 2006). A demographic profile of the sample is displayed in Table 3.

According to Table 3, a good balance has been achieved between the number of black $(48.8 \%)$ and white $(45.2 \%)$ candidates. However, coloured $(2.4 \%)$ and Indian $(3.2 \%)$ populations are underrepresented. The percentage of women $(76.2 \%)$ in this sample is much higher than that of men $(23.8 \%)$. Most of the participants in the sample $(54.1 \%)$ have obtained a degree, $37 \%$ hold a diploma and $8.9 \%$ a Grade 12 qualification.

Following the guideline of Van Zyl and Rothmann (2012), a dual distribution channel (electronic and hardcopy) was used to distribute the questionnaires since it yields higher response rates. First, electronic copies of the questionnaires were distributed via e-mail to individuals who had access to computers. Second, where individuals did not have access to computers, a hardcopy (pen-on-paper) version of the questionnaire was distributed. The covering letter included with each questionnaire invited respondents to participate voluntarily in the study and highlighted their rights and responsibilities. Participants were assured that their responses would remain confidential and would be used for research purposes only. Permission to conduct the research was obtained from the research ethics committee of the research institution. 
Table 3

Demographic profile of respondents

\begin{tabular}{|l|l|r|r|c|}
\hline \multicolumn{1}{|c|}{ Category } & Frequency & Valid \% & $\begin{array}{c}\text { Cumulative } \\
\%\end{array}$ \\
\hline \multirow{5}{*}{ Race } & Black & 121 & 48.8 & 48.8 \\
\cline { 2 - 5 } & Coloured & 6 & 2.4 & 51.2 \\
\cline { 2 - 5 } & Indian & 8 & 3.2 & 54.4 \\
\cline { 2 - 5 } & White & 112 & 45.2 & 99.6 \\
\cline { 2 - 5 } & Other & 1 & 0.40 & 100.0 \\
\cline { 2 - 5 } & Total & $\mathbf{2 4 8}$ & & 23.8 \\
\hline \multirow{5}{*}{ Qualification } & Male & 59 & 23.8 & $\mathbf{1 0 0 . 0}$ \\
\cline { 2 - 5 } & Female & 189 & 76.2 & 8.9 \\
\cline { 2 - 5 } & Total & $\mathbf{2 4 8}$ & & 45.9 \\
\cline { 2 - 5 } & Grade 12 & 22 & 8.9 & 63.0 \\
\cline { 2 - 5 } & Diploma & 91 & 37.0 & 100.0 \\
\cline { 2 - 5 } & Bachelor's degree & 42 & 17.1 & \\
\cline { 2 - 5 } & Postgraduate qualification & 91 & 37.0 & \\
\cline { 2 - 5 } & Missing value & 2 & & \\
\cline { 2 - 5 } & Total & $\mathbf{2 4 8}$ & & \\
\hline
\end{tabular}

Phase 6: Data analysis

An exploratory factor analysis (EFA) was performed to validate the underlying structure of the questionnaire (Worthington \& Whittaker 2006) and to determine the dimensionality of the set of items (Tabachnick \& Fidell 2013). To determine the factorability of the correlation matrix, Bartlett's test of sphericity and the Kaiser-MeyerOlkin (KMO) index of sampling adequacy were applied. In the EFA, the responses for the 39 items of the questionnaire were correlated and rotated, first using principle component analysis and then, once the factors had been identified, using the principle axis factoring extraction method to determine the hierarchical nature of the scale. The theoretical verification of the items in the instrument gave the researchers reason to believe that the factors were correlated; therefore, an oblique rotation method, namely, direct oblimin rotation, was used throughout the EFA (Field 2009).

Factor retention criteria as prescribed by Hair et al (2006) and Worthington and Whittaker (2006) were used. Although items with communality estimates of 0.30 to 0.40 are regarded as acceptable, items with communality estimates of 0.50 were preferred so that the practical significance of the item could be assumed (Hair et al 2006). Worthington and Whittaker (2006) suggested that items with communality estimates of less than 0.32 be removed from the instrument. This suggestion also applied to an item with a cross-loading that showed a difference of less than 0.15 from the item's highest factor loading. According to Hayton, Allen and Scarpello (2004), as many common factors as possible should be retained to explain at least $50 \%$ of the variance in the data set.

The accuracy of the scale, or its internal consistency, was assessed by calculating the Cronbach's alpha coefficient for each theoretical dimension. Hair et al (2006) suggested that an alpha coefficient of 0.70 was ideal, but added that an alpha coefficient of 0.60 was acceptable for exploratory research. 


\section{Results}

This section will provide an overview of the results obtained after applying the abovementioned statistical process. The EFA consisted of various exploratory steps as explained above; however, only the final model determined by the EFA was reported.

Sampling adequacy was determined by applying the Kaiser-Meyer-Olkin (KMO) index and Bartlett's test of sphericity. Table 4 indicates a KMO index of 0.965 , and a significance (sig) value of $p<.05$ for Bartlett's test of sphericity, which is a clear indication that the sample is suitable for factor analysis (Hair et al 2006).

Table 4

Results of KMO index and Bartlett's test of sphericity

\begin{tabular}{|l|l|c|}
\hline Kaiser-Meyer-Olkin index of sampling adequacy & 0.965 \\
\hline \multirow{3}{*}{ Bartlett's test of sphericity } & Approx. chi-square & 8391.143 \\
\cline { 2 - 3 } & Df & 741 \\
\cline { 2 - 3 } & Sig. & 0.000 \\
\hline
\end{tabular}

The EFA was conducted in two phases. First, a principal components analysis was performed on the entire set of items from each theoretical dimension to establish unidimensionality in the dimension itself. Thereafter, the five strongest items (items with the highest communality estimates (preferably higher than 0.60 according to Hair et al 2006) from each dimension were retained (giving a total of 20 items). Based on the recommendation of Garson (2002), a total of five items was considered to be a manageable size for each dimension since, according to them, an instrument should comprise at least four to six items per dimension in order to increase the likelihood that a factor analysis would truly reflect the underlying structure of the item pool. Another reason for selecting only five items was to ensure that a minimum number of items account for the maximum portion of the total variance represented by the particular dimension. Limiting the number of items in the questionnaire will reduce respondent fatigue and obsolescence since the questionnaire will only take a few minutes to complete (DeVellis 2012). A second principal components factor analysis was then performed on the selected five items of each dimension to see if their communality estimates were even stronger when compared with one another.

Once all the items with significantly lower communality estimates had been removed, the researcher conducted another factor analysis across all dimensions. In other words, the five best items from each dimension were included in the analysis. Therefore, the final analysis included 20 items consisting of the five best items from each of the four dimensions (trust, justice, fairness and good faith). The final instrument can be viewed in Addendum 2.

The aim of the final analysis was to test whether the data collected emphasised the same dimensions as those identified in the literature review. The computer software programme, SPSS version 21 (IBM Corporation 2012), was used to calculate the means, standard deviations and communality estimates (see Table 4), as well as the Cronbach's alpha coefficients. 
Table 4

Descriptive statistics, communality estimates and reliability coefficients of final analysis

\begin{tabular}{|c|c|c|c|c|c|}
\hline Variable & Mean & $\begin{array}{l}\text { Standard } \\
\text { deviation }\end{array}$ & \begin{tabular}{|c|} 
Common \\
variance \\
explained in \\
$1^{\text {st }}$ round \\
EFA
\end{tabular} & \begin{tabular}{|c|} 
Common \\
variance \\
explained in \\
$2^{\text {nd }}$ round \\
EFA
\end{tabular} & Alpha \\
\hline \multicolumn{6}{|l|}{ Justice } \\
\hline $\begin{array}{l}\text { My supervisor applies workplace rules and } \\
\text { codes correctly. }\end{array}$ & 5.420 & 1.391 & 0.760 & 0.782 & 0.896 \\
\hline $\begin{array}{l}\text { My supervisor adheres to the conditions in } \\
\text { my employment contract. }\end{array}$ & 5.520 & 1.319 & 0.685 & 0.683 & 0.904 \\
\hline $\begin{array}{l}\text { My supervisor complies with employment } \\
\text { laws. }\end{array}$ & 5.470 & 1.433 & 0.628 & 0.606 & 0.912 \\
\hline $\begin{array}{l}\text { My supervisor follows workplace policies. } \\
\text { codes. rules and procedures. }\end{array}$ & 5.670 & 1.293 & 0.710 & 0.703 & 0.904 \\
\hline $\begin{array}{l}\text { My supervisor adheres to the labour laws } \\
\text { that apply to our workplace. }\end{array}$ & 5.560 & 1.444 & 0.732 & 0.747 & 0.896 \\
\hline \multicolumn{6}{|l|}{ Fairness } \\
\hline $\begin{array}{l}\text { My supervisor does not show prejudice } \\
\text { when we interact. }\end{array}$ & 5.240 & 1.569 & 0.708 & 0.650 & 0.909 \\
\hline $\begin{array}{l}\text { My supervisor treats me the same as } \\
\text { he/she treats other employees who are my } \\
\text { equals. }\end{array}$ & 5.050 & 1.735 & 0.784 & 0.701 & 0.895 \\
\hline $\begin{array}{l}\text { My supervisor's actions and decisions in } \\
\text { the workplace are consistent. }\end{array}$ & 5.110 & 1.631 & 0.764 & 0.728 & 0.906 \\
\hline $\begin{array}{l}\text { My supervisor gives me and my co- } \\
\text { workers equal treatment. }\end{array}$ & 5.010 & 1.765 & 0.771 & 0.686 & 0.897 \\
\hline My supervisor is fair. & 5.130 & 1.709 & 0.590 & 0.719 & 0.906 \\
\hline \multicolumn{6}{|l|}{ Good faith } \\
\hline My supervisor is honest with me. & 5.130 & 1.590 & 0.753 & 0.733 & 0.890 \\
\hline My supervisor treats me with respect. & 5.610 & 1.469 & 0.696 & 0.629 & 0.889 \\
\hline $\begin{array}{l}\text { My supervisor deals with differences in a } \\
\text { constructive manner. }\end{array}$ & 5.130 & 1.486 & 0.773 & 0.701 & 0.890 \\
\hline $\begin{array}{l}\text { My supervisor really tries to reach } \\
\text { reasonable agreements with me. }\end{array}$ & 5.260 & 1.467 & 0.706 & 0.683 & 0.891 \\
\hline $\begin{array}{l}\text { My supervisor shows good faith by acting } \\
\text { in my best interests. }\end{array}$ & 5.100 & 1.552 & 0.734 & 0.715 & 0.890 \\
\hline \multicolumn{6}{|l|}{ Trust } \\
\hline $\begin{array}{l}\text { My supervisor gives good reasons to justify } \\
\text { his work decisions and actions. }\end{array}$ & 5.200 & 1.528 & 0.718 & 0.692 & 0.894 \\
\hline $\begin{array}{l}\text { My supervisor will stand by me when I am } \\
\text { in trouble. }\end{array}$ & 5.250 & 1.560 & 0.691 & 0.632 & 0.905 \\
\hline $\begin{array}{l}\text { My supervisor makes informed decisions } \\
\text { with regard to my work. }\end{array}$ & 5.250 & 1.427 & 0.730 & 0.638 & 0.907 \\
\hline $\begin{array}{l}\text { I trust my supervisor to make decisions on } \\
\text { my behalf. }\end{array}$ & 4.790 & 1.723 & 0.800 & 0.696 & 0.891 \\
\hline $\begin{array}{l}\text { I trust my supervisor to make decisions in } \\
\text { my best interests. }\end{array}$ & 4. 910 & 1.566 & 0.837 & 0.748 & 0.881 \\
\hline
\end{tabular}

Extraction method: Principal axis factoring 
As expected, the five strongest items of each theoretical dimension generated very high communality estimates when grouped together. When looking at the initial estimates, all items were above 0.60 and some estimates were above 0.80 , indicating a very strong common variance between the items. In the case of the trust dimension, $74.81 \%$ of the variance was explained, with a mean value of 5.077 and a standard deviation of 1.355. The percentage of variance explained was ideal, since it far exceeded the $50 \%$ recommended by Hayton et al (2004). The percentage of variance explained for the justice dimension was $75.97 \%$, with a mean value of 5.333 and a standard deviation of 1.203. In the case of the fairness dimension the percentage of variance explained was $75.93 \%$, the mean value 5.118 and the standard deviation 1.459 , and for the good faith dimension the percentage of variance explained was $73.60 \%$, with a mean value of 5.242 and a standard deviation of 1.304 .

The Cronbach's alpha for each reduced theoretical dimension (see Table 4) was calculated to determine the internal consistency of the items. The Cronbach's alpha coefficients of the items from each dimension were well above the guideline of 0.70 (Hair et al 2006), indicating a high internal consistency among the items within their theoretical dimensions.

To see which items formed groups, the researchers used the pattern matrix displayed in Table 5. Contrary to the researchers' initial expectation, two distinct factors emerged instead of four. The 15 items generated for trust, fairness and good faith emerged as a single factor. Owing to the relationship between these items and the psychological contract, this factor was labelled social conditions. The five compliance items were very closely related to the formal contract entered into by employer and employee, and were subsequently labelled compliance factors. Therefore, a questionnaire comprising twenty items with strong common variance and high internal consistency, measuring one construct with two distinct dimensions, was developed. The scale inter-correlation matrix for this two-factor model revealed that factor 1 , labelled social conditions, and factor 2, labelled compliance factors, correlated with one another $(R=0.778)$, indicating that these two factors are interrelated (Hair et al 2006). The Cronbach's alpha coefficients for these two factors were 0.969 for factor 1 (social conditions) and 0.920 for factor 2 (compliance factors) respectively, indicating good reliability (Hair et al 2006).

Table 5

Pattern matrix of final factor analysis

\begin{tabular}{|l|c|c|}
\hline \multicolumn{1}{|c|}{ C= Justice; F=Fairness; T= Trust; G= Good faith } & \multicolumn{2}{c|}{ Factor } \\
\cline { 2 - 3 } & $\mathbf{1}$ & $\mathbf{2}$ \\
\hline G: My supervisor shows good faith by acting in my best interests. & 0.905 & \\
\hline G: My supervisor really tries to reach reasonable agreements with me. & 0.905 & \\
\hline F: My supervisor treats me the same as other employees who are my equals. & 0.887 & \\
\hline T: I trust my supervisor to make decision in my best interests. & 0.886 & \\
\hline T: I trust my supervisor to make decisions on my behalf. & 0.855 & \\
\hline T: My supervisor will stand by me when I am in trouble. & 0.844 & \\
\hline F: My supervisor gives me and my co-workers equal treatment. & 0.794 & \\
\hline G: My supervisor treats me with respect. & 0.792 & \\
\hline G: My supervisor deals with differences in a constructive manner. & 0.786 & \\
\hline G: My supervisor is honest with me. & 0.715 & \\
\hline F: My supervisor does not show prejudice when we interact. & 0.713 & \\
\hline & \multicolumn{2}{c|}{ continued/ }
\end{tabular}




\begin{tabular}{|l|c|c|}
\hline \multicolumn{1}{|c|}{ C= Justice; F=Fairness; T= Trust; G= Good faith } & \multicolumn{2}{c|}{ Factor } \\
\cline { 2 - 3 } & $\mathbf{1}$ & $\mathbf{2}$ \\
\hline T: My supervisor gives good reasons to justify his work decisions and actions. & 0.620 & \\
\hline F: My supervisor is fair. & 0.612 & \\
\hline T: My supervisor makes informed decisions with regard to my work. & 0.590 & \\
\hline F: My supervisor's actions and decisions in the workplace are consistent. & 0.581 & \\
\hline C: My supervisor adheres to the labour laws that apply to our workplace. & & 0.909 \\
\hline C: My supervisor applies workplace rules and codes correctly. & & 0.853 \\
\hline C: My supervisor follows workplace policies, codes, rules and procedures. & & 0.833 \\
\hline C: My supervisor adheres to the conditions in my employment contract. & & 0.737 \\
\hline C: My supervisor complies with employment laws. & & 0.599 \\
\hline
\end{tabular}

Extraction method: Principal axis factoring

Rotation method: Oblimin with Kaiser Normalization ${ }^{a}$

${ }^{a}$ Rotation converged in five iterations

\section{Discussion}

Employee Relations (ER) developed as a result of the need to look at the human aspect of the employment relationship, prompting a shift from focusing on only the legal aspects of the relationship to attending to the social aspects of the relationship as well (Bendix 2010a). Formal conditions alone cannot create a good employment relationship. The social conditions of trust, fairness and good faith determine employees' perception of the supervisory relationship. Furthermore, this study reestablished the importance of supervisory relationships and their effect on employees in terms of the way they behave towards the organisation and their intention to stay with the organisation.

The aim of this study was to develop a valid and reliable measure of the perceived quality of supervisory relationships (relationships between employees and direct supervisors) from the employee's perspective. This measure could help supervisors and practitioners to identify their strengths and weaknesses according to the perceptions of their subordinates. Obtaining this information can assist supervisors in taking either remedial or reinforcing action to enhance the quality of the relationship between them and their subordinates.

Four dimensions of PERQ were derived from the theory: trust, justice, fairness and good faith. The statistical analysis, however, revealed two distinct dimensions. Owing to their composition, the dimensions were labelled "social factors" and "compliance factors". The social dimension comprises items stemming from the trust, fairness and good faith dimensions, which are considered to be rather subjective, whereas the compliance dimension comprises items relating to more objective and unambiguous themes, such as codes, policies and procedures.

The fact that the statistical analysis revealed two distinct dimensions, one being a social dimension and the other a more normative dimension, shows that compliance with terms and conditions is not the only expectation that employees have. This confirms the existence of a psychological contract in conjunction with the formal contract, as suggested by Mclnnis, Meyer and Feldman (2009), Robinson (1996) and Roehling (1997).

Unlike many climate surveys and job-satisfaction questionnaires that address employment terms and conditions, the instrument developed in this study focuses 
specifically on the relationship between employer (supervisor) and employee. It is selfevident that employees may be satisfied with the terms and conditions of their contract and the application thereof, but might be unhappy with their interactions with their immediate supervisors. Porter and Steers (1973) and Tuttle (1986) support this by highlighting negative supervisory relationships as one of the reasons why people withdraw from their organisations.

Since the dimensions of this questionnaire have been clearly established, a more refined version of this instrument would be a useful tool for evaluating managers from the perspective of an employee. Dessler (2008) pointed out that as part of the performance management process supervisors could be evaluated and rated by their subordinates. This instrument could therefore be used during the performance management process to assess how employees perceived the quality of their relationship with their supervisors. Based on this information, the instrument would indicate whether employers should take remedial or investigative action where necessary to enhance the quality of the relationship between supervisors and their subordinates.

\section{Limitations and recommendations}

An exploratory study such as this is not without limitations. The sample size was not large enough for the data to be split into random subsets to perform various multivariate analyses, as suggested by Hair et al (2006). Hinkin (1998) suggested that numerous independent samples should be collected, as many of the multivariate techniques could be sample-specific. The instrument should, therefore, be subjected to further analysis, using an independent sample to perform a confirmatory factor analysis. In addition, items could be further reviewed and refined to make them more specific and to reduce response bias. Common method bias could have been introduced as a result of the method of self-reporting, which limited the responses of participants to the items included in the instrument, and prevented the capture of the richness and variety of possible responses.

This questionnaire was designed to measure PERQ from the subordinate's perspective. A similar questionnaire measuring $P E R Q$ from management's perspective could be equally useful. If these questionnaires were used in conjunction with each other, employers could gain in-depth insight into the quality of relationships within their organisation.

\section{Conclusion}

The key contribution of this study was the development of a questionnaire to measure $P E R Q$. This study has further confirmed that formal conditions alone cannot create a good employment relationship. Trust, fairness and good faith are social conditions that determine employees' perception of a supervisory relationship. Furthermore, this study has re-established the importance of supervisory relationships and their effect on employees in terms of their behaviour towards their organisations and their intention to stay with their organisations. This instrument could be used by management and employers to establish how employees perceive their relationship with their supervisor, which would indicate whether managers and employees are experiencing optimal work relationships. Although a questionnaire was developed to measure $P E R Q$, it is important to realise that scale development is an ongoing process and continued refinement of the PERQ questionnaire is therefore necessary. 


\section{List of References}

Adams, JS. 1965. Inequity in social exchange. Advances in Experimental Social Psychology 2:267-299.

Barnette, JJ. 2000. Effects of stem and Likert response option reversals on survey internal consistency: If you feel the need, there is a better alternative to using those negatively worded items. Educational and Psychological Measurement 60(3): 361-370.

Bendix, S. 2010a. Industrial relations in South Africa. $5^{\text {th }}$ edition. Cape Town: Juta.

Bendix, S. 2010b. Labour relations in practice: An outcomes-based approach. Cape Town: Juta.

Bews, N \& Uys, T. 2002. The impact of organisational restructuring on perceptions of trustworthiness. South African Journal of Industrial Psychology 28(4):21-28.

Botha, L \& Moalusi, KP. 2010. Values underlying perceptions of breach of the psychological contract. SA Journal of Industrial Psychology 36(1):1-12.

Burke, CS, Sims, DE, Lazzara, EH \& Salas, E. 2007. Trust in leadership: A multi-level review and integration. The Leadership Quarterly 18(6):606-632.

Clark, MC \& Payne, RL. 1997. The nature and structure of workers' trust in management. Journal of Organizational Behavior 18(3):205-224.

Coetzee, M \& Bezuidenhout, M. 2011. The fairness of affirmative action: In the eye of the beholder. Southern African Business Review 15(2):75-96.

Colquitt, JA, Conlon, DE, Wesson, MJ, Porter \& Ng, KY. 2001. Justice at the millennium: A meta-analytical review of 25 years of organizational justice research. Journal of Applied Psychology 86(3):425-445.

Coyle-Shapiro, JA-M \& Shore, LM. 2007. The employee-organization relationship: Where do we go from here? Human Resource Management Review 17(2):166-179.

Cremer, DD \& Tyler, TR. 2007. The effects of trust in authority and procedural fairness on cooperation. Journal of Applied Psychology 92(3):639-649.

Cropanzana, R, Bowen, DE, Gilliland, SW, \& Bowen, E. 2007. The management of organizational justice. Academy of Management Perspectives 21(4):34-48.

Deci, EL, Connell, JP \& Ryan, RM. 1989. Self-determination in a work organization. Journal of Applied Psychology 74(4):580-590.

De La Rosa Navarro, M \& Cabrera, EF. 2009. A typolgy of employment relationships: A multi-disciplinary approach. Psychology in Spain 13(1):72-88.

Dessler, G. 2008. Human resource management. Upper Saddle River: Pearson.

DeVellis, RF. 2012. Scale development: Theory and practice. $3^{\text {rd }}$ edition. Thousand Oaks, CA: Sage.

Ehlers, L. 2013. A typology for desirable employment relationship conditions in supervisory relationships. South African Journal of Labour Relations 37(2):48-68.

Field, A. 2009. Discovering statistics using SPSS. $3^{\text {rd }}$ edition. London: Sage.

Furlow, C. 2009. Good faith, fiduciary duties, and the business judgment rule in Delaware. Utah Law Review 3:1061-1095. 
Garson, GD. 2002. Statnotes: Topics in multivariate analysis. Factor analysis. Available at: http://faculty.chass.ncsu.edu/garson/PA765/statnote.htm (accessed on 5 July 2013).

Gerlach, K, Levine, D, Stephan, G \& Struck, O. 2007. Fairness and the employment contract: North American regions versus Germany. Cambridge Journal of Economics 32(3):421-439.

Gould-Williams, J. 2003. The importance of HR practices and workplace trust in achieving superior performance: A study of public-sector organizations. International Journal of Human Resource Management 14(1):28-54.

Grant, JS \& Davis, LL. 1997. Focus on quantitative methods selection and use of content experts for instrument development. Research in Nursing \& Health 20:269274.

Graziano, AM \& Raulin, ML. 2004. Research methods: A process of inquiry. $5^{\text {th }}$ edition. Upper Saddle River, NJ: Pearson Education Group.

Greenberg, J. 2001. Studying organizational justice cross-culturally: Fundamental challenges. International Journal of Conflict Management 12(4):365-375.

Grogan, J. 2009. Workplace law. $10^{\text {th }}$ edition. Cape Town: Juta.

Guest, DE. 2004. The psychology of the employment relationship: An analysis based on the psychological contract. Applied Psychology 53(4):541-555.

Hair, JF, Black, WC, Babin, BJ, Anderson, RE \& Tatham, RL. 2006. Multivariate data analysis. $6^{\text {th }}$ edition. Upper Saddle River: Pearson Prentice-Hall.

Hallier, J \& James, P. 1997. Management-enforced job change and employee perceptions of the psychological contract. Employee Relations 19(3):222-247.

Hayton, JC, Allen, DG \& Scarpello, V. 2004. Factor retention decisions in exploratory factor analysis: A tutorial on parallel analysis. Organizational Research Methods 7(2):191-205.

Hinkin, TR. 1998. A brief tutorial on the development of measures for use in questionnaires. Organisational Research Methods 1(1):104-121.

IBM SPSS Statistics. 2012. SPSS for Windows 21. Chicago: SPSS Inc.

Khodyakov, D. 2007. Trust as a process: A three-dimensional approach. Sociology 41(1):115-132.

Kickul, J, Gundry, LK \& Posig, M. 2005. Does trust matter? The relationship between equity sensitivity and perceived organizational justice. Journal of Business Ethics 56(3):205-218.

Kolm, S. 2006. Reciprocity: Its scope, rationales, and consequences. In: Kolm, S \& Ythier, JM (eds). Handbook of the economics of giving, altruism and reciprocity. London: Elsevier. pp 371-541.

Lind, E \& Van den Bos, K. 2002. When fairness works: Towards a general theory of uncertainty. Research in Organizational Behaviour 24:181-223.

Mclnnis, KJ, Meyer, JP \& Feldman, S. 2009. Psychological contracts and their implications for commitment: A feature-based approach. Journal of Vocational Behavior 74(2):165-180.

Nelson, ML \& Friedlander, ML. 2001. A close look at conflictual supervisory relationships: The trainee perspective. Journal of Counselling Psychology 48(4):384-395. 
Nowakowski, J M \& Conlon, DE. 2005. Organizational justice: Looking back, looking forward. International Journal of Conflict Management 16(1):4-29.

Porter, LW \& Steers, RM. 1973. Organizational, work, and personal factors in employee turnover and absenteeism. Psychological Bulletin 80(2):151-176.

Rattray, J \& Jones, MC. 2007. Essential elements of questionnaire design and development. Journal of Clinical Nursing 16(2):234-43.

Robbins, S \& Judge, T. 2011. Organizational behaviour. $14^{\text {th }}$ edition. Boston: Pearson.

Robinson, SL. 1996. Trust and breach of the psychological contract. Administrative Science Quarterly 41(4):574-599.

Roehling, MV. 1997. The origins and early development of the psychological contract construct. Journal of Management History 3(2):204-207.

Rousseau, DM. 1995. Psychological contract in organizations: Understanding written and unwritten agreements. Thousand Oaks: Sage.

Rousseau, DM. 1998. The problem of the psychological contract considered. Journal of Organizational Behavior 19:665-671.

Salamon, M. 1987. Industrial relations: Theory and practice. London: Prentice-Hall.

Schmitt, NW \& Stults, DM. 1985. Factors defined by negatively keyed items: The results of careless respondents. Applied Psychology Measurement 9:367-373.

Searle, R \& Skinner, D. 2011. Trust and human resource management. Cheltenham: Edward Elgar.

Shanock, LR \& Eisenberger, R. 2006. When supervisors feel supported: Relationships with subordinates, perceived supervisor support, perceived organizational support, and performance. Journal of Applied Psychology 91(3):689-695.

Shimanskaya, I. 2010. The principle of good faith in European international trade. Master's Thesis. University of Tampere, Tampere, Finland. Available at: http://tutkielmat.uta.fi/pdf/gradu04157.pdf (accessed on 5 July 2013).

Shore, LM \& Barksdale, K. 1998. Examining degree of balance and level of obligation in the employment relationship: A social exchange approach. Journal of Organizational Behavior 19(S1):731-744.

Shore, T, Sy, T, \& Strauss, J. 2006. Leader responsiveness, equity sensitivity, and employee attitudes and behavior. Journal of Business and Psychology 21(2): 227-241.

Southey, K. 2010. A typology of employee explanations of misbehaviour: An analysis of unfair dismissal cases. Journal of Industrial Relations 52(1):81-102.

Sparrow, P \& Cooper, C. 2003. The employment relationship: Key challenges for HR. London: Butterworth-Heinemann.

Tabachnick, BG \& Fidell, LS. 2013. Using multivariate statistics. $6^{\text {th }}$ edition. Boston: Pearson.

Tekleab, AG \& Taylor, MS. 2003. Aren't there two parties in an employment relationship? Antecedents and consequences of organization-employee agreement on contract obligations and violations. Journal of Organizational Behavior 24(5): 585-608.

Thau, S, Bennett, RJ, Mitchell, MS, \& Marrs, MB. 2009. How management style moderates the relationship between abusive supervision and workplace deviance: 
An uncertainty management theory perspective. Organizational Behavior and Human Decision Processes 108(1):79-92.

Thibaut, J \& Walker, L. 1975. Procedural justice: A psychological perspective. Hillsdale: $\mathrm{NJ}$ : Erlbaum.

Tepper, BJ, Carr, JC, Breaux, DM, Geder, S, Hu, C \& Hua, W. 2009. Abusive supervision, intentions to quit, and employees' workplace deviance: A power/dependence analysis. Organizational Behavior and Human Decision Processes 109:156-167.

Tuttle, M. 1986. Employee turnover: A meta-analysis and review with implications for research. Academy of Management 11(1):55-70.

Van Zyl, L. E., \& Rothmann, S. 2012. Flourishing of students in a tertiary education institution in South Africa. Journal of Psychology in Africa 22(4):593-599.

Venter, R \& Levy, A. (eds.). 2011. Labour relations in South Africa. $4^{\text {th }}$ edition. Cape Town: Oxford University Press.

Wallace, J, Hunt, J \& Richards, C. 1999. The relationship between organisational culture, organisational climate and managerial values. International Journal of Public Sector Management 12(7):548-564.

Whitener, EM, Brodt, SE, Korsgaard, MA \& Werner, JM. 2014. Managers as initiators of trust: An exchange relationship framework for understanding managerial trustworthy behaviour. Academy of Management 23(3):513-530.

Woods, CM. 2006. Careless responding to reverse-worded items: Implications for confirmatory factor analysis. Journal of Psychopathology and Behavioral Assessment 28(3):186-191.

Worthington, RL \& Whittaker, TA. 2006. Scale development research: A content analysis and recommendations for best practices. Counseling Psychologist 34(6):806-838. 


\section{Addendum 1: Item Substantiation}

This Appendix reflects the theoretical justification for each item that was developed and included in the pilot questionnaire. Here, the questions were grouped according to the dimension of the typology they are related to.

\begin{tabular}{|c|c|c|}
\hline \multicolumn{3}{|c|}{ Four dimensions and descriptive elements of PERQ } \\
\hline No & Item & Theoretical verification \\
\hline & $\begin{array}{l}\text { Trust: } \\
\text { Trust can be defined as "a willingness to rely } \\
\text { or depend on some externality such as an } \\
\text { event, process, individual, group or system" } \\
\text { (Clark \& Payne 1997: 208). }\end{array}$ & \\
\hline 1. & I trust my supervisor & Standard question for statistical purposes \\
\hline 2. & $\begin{array}{l}\text { I trust my supervisor to make decisions on } \\
\text { my behalf. }\end{array}$ & $\begin{array}{l}\text { Clark and Payne (1997) define trust as "a } \\
\text { willingness to rely or depend on some externality } \\
\text { such as an event, process, individual, group or } \\
\text { system". Rousseau (1998) also defines trust as } \\
\text { "a psychological state comprising the intention to } \\
\text { accept vulnerability based upon positive } \\
\text { expectations of the intentions or behaviour of } \\
\text { another". }\end{array}$ \\
\hline 3. & $\begin{array}{l}\text { I trust my supervisor to make decisions in my } \\
\text { best interests. }\end{array}$ & Variation of question 2 for EFA purposes \\
\hline 4. & $\begin{array}{l}\text { My supervisor gives good reasons to justify } \\
\text { his/her work decisions and actions }\end{array}$ & $\begin{array}{l}\text { Robbins and Judge (2011) consider integrity as } \\
\text { a determinant of trust. }\end{array}$ \\
\hline 5. & $\begin{array}{l}\text { My supervisor will stand by me when I am in } \\
\text { trouble. }\end{array}$ & $\begin{array}{l}\text { This question was highlighted in a pilot study. } \\
\text { Participants regarded this item as an important } \\
\text { determinant of trust. }\end{array}$ \\
\hline 6. & $\begin{array}{l}\text { My supervisor makes informed decisions } \\
\text { with regard to my work. }\end{array}$ & $\begin{array}{l}\text { Item adapted from the Minnesota Job } \\
\text { Satisfaction Questionnaire (no 6). }\end{array}$ \\
\hline 7. & $\begin{array}{l}\text { My supervisor engages in sound Human } \\
\text { Resource Management practices. }\end{array}$ & $\begin{array}{l}\text { Coyle-Shapiro and Shore (2007); Gould-Williams } \\
\text { (2003) indicated that there is a positive } \\
\text { relationship between good HRM practices and } \\
\text { levels of trust. }\end{array}$ \\
\hline 8. & $\begin{array}{l}\text { My supervisor can be relied upon to give } \\
\text { good guidance to his subordinates. }\end{array}$ & $\begin{array}{l}\text { Adapted from a climate survey and supported by } \\
\text { Clark and Payne (1997), who propose that trust } \\
\text { means voluntarily relying on someone else. }\end{array}$ \\
\hline 9. & $\begin{array}{l}\text { My supervisor will not lie to his/her } \\
\text { subordinates. }\end{array}$ & $\begin{array}{l}\text { Robbins et al (2011) consider integrity to be a } \\
\text { determinant of trust. }\end{array}$ \\
\hline 10. & $\begin{array}{l}\text { My supervisor will keep his/her promises to } \\
\text { me. }\end{array}$ & Variation of question 9 for EFA purposes. \\
\hline 11. & $\begin{array}{l}\text { My supervisor displays good leadership traits } \\
\text { in his role. }\end{array}$ & $\begin{array}{l}\text { Coyle-Shapiro and Shore (2007); Gould-Williams } \\
\text { (2003) states that good leadership affects trust } \\
\text { positively. }\end{array}$ \\
\hline & $\begin{array}{l}\text { Justice: } \\
\text { Justice and its subdivisions are associated } \\
\text { with normative behaviour with regard to the } \\
\text { application of legal aspects of the } \\
\text { employment contract (Colquitt, Conlon, } \\
\text { Wesson, Porter \& Ng 2001). }\end{array}$ & $\begin{array}{l}\text { Items for this dimensions were based on a } \\
\text { framework of justifiable employment relationship } \\
\text { behaviour developed by Ehlers (2013). The } \\
\text { framework was based on the work of Bendix } \\
\text { (2010a) and Grogan (2009). The framework was } \\
\text { displayed in Figure } 2.1 \text { in the literature review. }\end{array}$ \\
\hline 12. & My superior complies with employment laws. & $\begin{array}{l}\text { Derived from the framework in the literature } \\
\text { discussion. }\end{array}$ \\
\hline 13. & $\begin{array}{l}\text { My supervisor adheres to the labour laws } \\
\text { that apply to our workplace. }\end{array}$ & $\begin{array}{l}\text { Derived from the framework in literature } \\
\text { discussion. }\end{array}$ \\
\hline 14. & My supervisor applies workplace rules and & Variation of question 13 for EFA purposes. \\
\hline
\end{tabular}




\begin{tabular}{|c|c|c|}
\hline \multicolumn{3}{|c|}{ Four dimensions and descriptive elements of PERQ } \\
\hline No & Item & Theoretical verification \\
\hline & codes correctly. & \\
\hline 15. & $\begin{array}{l}\text { My supervisor adheres to the conditions in } \\
\text { my employment contract. }\end{array}$ & $\begin{array}{l}\text { Derived from the framework in literature } \\
\text { discussion. }\end{array}$ \\
\hline 16. & $\begin{array}{l}\text { My supervisor follows workplace policies, } \\
\text { codes, rules and procedures. }\end{array}$ & $\begin{array}{l}\text { Derived from the framework in literature } \\
\text { discussion. }\end{array}$ \\
\hline 17. & $\begin{array}{l}\text { My supervisor will keep my confidential } \\
\text { information secret. }\end{array}$ & $\begin{array}{l}\text { Confidentiality of personal information is a legal } \\
\text { requirement of the Labour Relations Act. }\end{array}$ \\
\hline \multirow[t]{2}{*}{18.} & $\begin{array}{l}\text { My supervisor does not infringe my } \\
\text { constitutional rights. }\end{array}$ & $\begin{array}{l}\text { Derived from the framework in literature } \\
\text { discussion. }\end{array}$ \\
\hline & $\begin{array}{l}\text { Fairness: } \\
\text { Fairness refers to consistent treatment of } \\
\text { different people in similar situations } \\
\text { (Salamon 1987). }\end{array}$ & \\
\hline 19. & My supervisor is fair. & Standard question for statistical purposes. \\
\hline 20. & $\begin{array}{l}\text { My supervisor does not show prejudice } \\
\text { towards me when we interact. }\end{array}$ & $\begin{array}{l}\text { Any prejudged action can be regarded as unfair } \\
\text { (Bendix 2010a). }\end{array}$ \\
\hline 21. & $\begin{array}{l}\text { My supervisor's expectations with regard to } \\
\text { my work are reasonable. }\end{array}$ & $\begin{array}{l}\text { Colquitt et al (2001) and Cropanzano et al } \\
\text { (2007) study fairness from a legal perspective } \\
\text { and apply the reasonability test to judge fairness. } \\
\text { Since participants are not expected to be legal } \\
\text { experts, their own perception of reasonability is } \\
\text { sufficient to determine fairness. }\end{array}$ \\
\hline 22. & $\begin{array}{l}\text { My supervisor hears me out before making a } \\
\text { decision about my actions. }\end{array}$ & A variation of question 20 \\
\hline 23. & $\begin{array}{l}\text { My supervisor treats me the same as other } \\
\text { employees who are my equals. }\end{array}$ & $\begin{array}{l}\text { Consistent treatment of different employees in } \\
\text { similar situations is a prerequisite for fairness } \\
\text { according to Bendix (2010a). }\end{array}$ \\
\hline 24. & $\begin{array}{l}\text { My supervisor's actions and decisions in the } \\
\text { workplace are consistent. }\end{array}$ & $\begin{array}{l}\text { Salamon (1987) states that consistent behaviour } \\
\text { is a prerequisite for fair treatment }\end{array}$ \\
\hline 25. & $\begin{array}{l}\text { My supervisor gives equal treatment to me } \\
\text { and my co-workers. }\end{array}$ & A variation of question 26. \\
\hline 26. & $\begin{array}{l}\text { My supervisor performs his/her duties before } \\
\text { expecting employees to perform their duties. }\end{array}$ & $\begin{array}{l}\text { Reciprocity is a prerequisite of perceived } \\
\text { fairness (Kolm 2006). }\end{array}$ \\
\hline \multirow[t]{2}{*}{27.} & My supervisor rewards me for my work. & $\begin{array}{l}\text { Reciprocity is a prerequisite of perceived } \\
\text { fairness (Kolm 2006). }\end{array}$ \\
\hline & $\begin{array}{l}\text { Good faith: } \\
\text { Good faith implies that contracting parties } \\
\text { should be honest, sincere, fair and } \\
\text { cooperative during dispute settlements, } \\
\text { performance management, collective } \\
\text { bargaining, contracting, negotiating and all } \\
\text { other forms of interaction in the employment } \\
\text { relationship (Ehlers 2013). }\end{array}$ & \\
\hline 28. & My supervisor generally acts in good faith. & Standard question for statistical purposes. \\
\hline 29. & $\begin{array}{l}\text { My supervisor shows good faith by acting in } \\
\text { my best interests. }\end{array}$ & Variation of question 28 for EFA purposes. \\
\hline 30. & My supervisor is honest with me. & $\begin{array}{l}\text { Grogan (2009) states that honesty is a } \\
\text { prerequisite of good faith. } \\
\text { This question also appears in the Organisational } \\
\text { Perception Survey that BE @ UP conducted for } \\
\text { the SA Mint. }\end{array}$ \\
\hline 31. & My supervisor treats me with respect. & $\begin{array}{l}\text { Riley, Lorraine, Heap, Rathmell and Sarina, } \\
\text { (2009) states that acting in good faith means that }\end{array}$ \\
\hline
\end{tabular}




\begin{tabular}{|c|c|c|}
\hline \multicolumn{3}{|c|}{ Four dimensions and descriptive elements of PERQ } \\
\hline No & Item & Theoretical verification \\
\hline & & $\begin{array}{l}\text { one is not acting in bad faith. Respect towards } \\
\text { another means there is an absence of bad faith. }\end{array}$ \\
\hline 32. & $\begin{array}{l}\text { My supervisor deals with differences in a } \\
\text { constructive manner. }\end{array}$ & $\begin{array}{l}\text { Riley et al (2009) states that conflict or problems } \\
\text { should be dealt with in a cooperative, sincere } \\
\text { and firm manner. The interest of both parties } \\
\text { should be protected and promoted. }\end{array}$ \\
\hline 33. & $\begin{array}{l}\text { My supervisor sincerely tries to understand } \\
\text { and solve my work problems. }\end{array}$ & $\begin{array}{l}\text { Sincerity and acting in the best interest of the } \\
\text { working relationship is an act of good faith } \\
\text { (Bendix 2010a). }\end{array}$ \\
\hline 34. & $\begin{array}{l}\text { My supervisor really tries to reach } \\
\text { reasonable agreements with me. }\end{array}$ & $\begin{array}{l}\text { Supervisors should try to reach mutually } \\
\text { beneficial agreements with subordinates and } \\
\text { bargain in good faith (Bendix 2010a). }\end{array}$ \\
\hline 35. & $\begin{array}{l}\text { My supervisor does not engage in insulting } \\
\text { behaviour. }\end{array}$ & $\begin{array}{l}\text { Bendix (2010a), Grogan (2009) and Venter and } \\
\text { Levy (2011) state that not engaging in insulting } \\
\text { behaviour is an act of good faith. }\end{array}$ \\
\hline 36. & $\begin{array}{l}\text { My supervisor does not engage in any } \\
\text { abusive behaviour. }\end{array}$ & $\begin{array}{l}\text { Bendix (2010a), Grogan (2009) and Venter and } \\
\text { Levy (2011) state that abusive behaviour is an } \\
\text { act of bad faith. }\end{array}$ \\
\hline 37. & $\begin{array}{l}\text { My supervisor does not make unilateral } \\
\text { decisions (changes are not made without first } \\
\text { consulting the people affected by them). }\end{array}$ & $\begin{array}{l}\text { Bendix (2010a), Grogan (2009) and Venter and } \\
\text { Levy (2011) state that making unilateral } \\
\text { decisions is an act of bad faith. }\end{array}$ \\
\hline 38. & $\begin{array}{l}\text { My supervisor provides sound arguments for } \\
\text { decisions that were made. }\end{array}$ & $\begin{array}{l}\text { Bendix (2010a), Grogan (2009) and Venter and } \\
\text { Levy (2011) state that explaining and providing } \\
\text { sound reasons for your position as superior is an } \\
\text { act of good faith. }\end{array}$ \\
\hline 39. & $\begin{array}{l}\text { My supervisor does not make decisions that } \\
\text { will only benefit him/herself. }\end{array}$ & $\begin{array}{l}\text { Riley et al (2009) believes that good faith implies } \\
\text { that both parties can benefit from the } \\
\text { interactions. }\end{array}$ \\
\hline 40. & $\begin{array}{l}\text { The support that I receive from my } \\
\text { supervisor is of good quality. }\end{array}$ & Control question \\
\hline 41. & $\begin{array}{l}\text { The social exchanges between me and } \\
\text { my supervisor are of good quality. }\end{array}$ & Control question \\
\hline 42. & $\begin{array}{l}\text { I am satisfied with general employment } \\
\text { conditions and employment relations at work. }\end{array}$ & Control question \\
\hline 43. & $\begin{array}{l}\text { I have a good relationship with my } \\
\text { supervisor. }\end{array}$ & Control question \\
\hline 44. & $\begin{array}{l}\text { I want to resign from my job because I am } \\
\text { dissatisfied with my supervisor. }\end{array}$ & Negative directed control question \\
\hline
\end{tabular}




\section{Addendum 2: Final measure for Perceived Employment Relationship Quality (PERQ)}

The following list contains 20 statements about the way your immediate supervisor behaves in your employment relationship. Consider the statements and indicate how strongly you agree or disagree with each statement by selecting your response from the options in the scale. Please answer all questions.

\begin{tabular}{|c|c|c|c|c|c|c|c|c|}
\hline & $\begin{array}{l}\text { Please indicate the way your immediate } \\
\text { supervisor behaves in your } \\
\text { employment relationship }\end{array}$ & 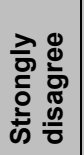 & 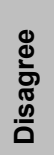 & 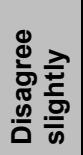 & 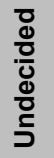 & 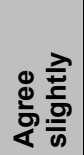 & ষ্ّ & 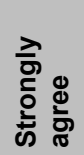 \\
\hline 1. & $\begin{array}{l}\text { My supervisor shows good faith by acting } \\
\text { in my best interests. }\end{array}$ & 1 & 2 & 3 & 4 & 5 & 6 & 7 \\
\hline 2. & $\begin{array}{l}\text { I trust my supervisor to make decision in } \\
\text { my best interests. }\end{array}$ & 1 & 2 & 3 & 4 & 5 & 6 & 7 \\
\hline 3. & $\begin{array}{l}\text { I trust my supervisor to make decisions on } \\
\text { my behalf. }\end{array}$ & 1 & 2 & 3 & 4 & 5 & 6 & 7 \\
\hline 4. & $\begin{array}{l}\text { My supervisor treats me the same as other } \\
\text { employees who are my equals. }\end{array}$ & 1 & 2 & 3 & 4 & 5 & 6 & 7 \\
\hline 5. & $\begin{array}{l}\text { My supervisor will stand by me when I am } \\
\text { in trouble. }\end{array}$ & 1 & 2 & 3 & 4 & 5 & 6 & 7 \\
\hline 6. & $\begin{array}{l}\text { My supervisor deals with differences in a } \\
\text { constructive manner }\end{array}$ & 1 & 2 & 3 & 4 & 5 & 6 & 7 \\
\hline 7. & $\begin{array}{l}\text { My supervisor gives equal treatment to me } \\
\text { and my co-workers. }\end{array}$ & 1 & 2 & 3 & 4 & 5 & 6 & 7 \\
\hline 8. & My supervisor treats me with respect. & 1 & 2 & 3 & 4 & 5 & 6 & 7 \\
\hline 9. & My supervisor is honest with me. & 1 & 2 & 3 & 4 & 5 & 6 & 7 \\
\hline 10. & $\begin{array}{l}\text { My supervisor does not show prejudice } \\
\text { when we interact. }\end{array}$ & 1 & 2 & 3 & 4 & 5 & 6 & 7 \\
\hline 11. & $\begin{array}{l}\text { My supervisor gives good reasons to } \\
\text { justify his work decisions and actions. }\end{array}$ & 1 & 2 & 3 & 4 & 5 & 6 & 7 \\
\hline 12. & $\begin{array}{l}\text { My supervisor's actions and decisions in } \\
\text { the workplace are consistent. }\end{array}$ & 1 & 2 & 3 & 4 & 5 & 6 & 7 \\
\hline 13. & $\begin{array}{l}\text { My supervisor really tries to reach } \\
\text { reasonable agreements with me. }\end{array}$ & 1 & 2 & 3 & 4 & 5 & 6 & 7 \\
\hline 14. & My supervisor is fair. & 1 & 2 & 3 & 4 & 5 & 6 & 7 \\
\hline 15. & $\begin{array}{l}\text { My supervisor makes informed decisions } \\
\text { with regard to my work. }\end{array}$ & 1 & 2 & 3 & 4 & 5 & 6 & 7 \\
\hline 16. & $\begin{array}{l}\text { My supervisor adheres to the labour laws } \\
\text { that apply to our workplace. }\end{array}$ & 1 & 2 & 3 & 4 & 5 & 6 & 7 \\
\hline 17. & $\begin{array}{l}\text { My supervisor applies workplace rules and } \\
\text { codes correctly. }\end{array}$ & 1 & 2 & 3 & 4 & 5 & 6 & 7 \\
\hline 18. & $\begin{array}{l}\text { My supervisor follows workplace policies, } \\
\text { codes, rules and procedures. }\end{array}$ & 1 & 2 & 3 & 4 & 5 & 6 & 7 \\
\hline 19. & $\begin{array}{l}\text { My supervisor adheres to the conditions in } \\
\text { my employment contract. }\end{array}$ & 1 & 2 & 3 & 4 & 5 & 6 & 7 \\
\hline 20. & $\begin{array}{l}\text { My supervisor complies with employment } \\
\text { laws. }\end{array}$ & 1 & 2 & 3 & 4 & 5 & 6 & 7 \\
\hline
\end{tabular}

